\title{
PENERAPAN PEMBIAYAAN MUSYARAKAH PADA BMT DANA BAROKAH MUNTILAN
}

\author{
Shinta Amelia Kurniasari, Risma Wira Bharata \\ Universitas Tidar Magelang, Indonesia \\ shintaameliakurniasari@gmail.com,rismawirab@gmail.com \\ https://doi.org/10.46367/jas.v4i2.240
}

Received: Oct 11, 2020 Revised: Nov 11, 2020 Accepted: Nov 13, 2020 Published: Dec 16, 2020

\begin{abstract}
This study aims to determine the implementation of profit sharing based musyarakah contracts, financing products and financing mechanisms at the Baitul Maal wa Tamwil (BMT) Dana Barokah. This study uses a qualitative method with a case study approach. The data used in the study used primary data and viewed from the data collection sources, the data used came from direct interviews with tellers and managers at BMT. The results of this study explain that BMT provides several savings products and financing products. To apply for financing, customers must first fill out a form and then complete the required files. In the implementation of musyarakah financing at BMT Dana Barokah Muntilan it is in accordance with Islamic sharia principles and the division of business with profit sharing, but the bank only as a provider of capital does not participate in conducting business activities. The profit-sharing determined by BMT Dana Barokah Muntilan is 2.5\%, but negotiations are still possible.
\end{abstract}

Keywords: Sharia, Musyarakah Financing, Profit Sharing.

\begin{abstract}
ABSTRAK
Penelitian ini bertujuan untuk mengetahui penerapan akad musyarakah berbasis bagi hasil, produk pembiayaan dan mekanisme pembiayaan pada Baitul Maal wa Tamwil (BMT) Dana Barokah. Penelitian ini menggunakan metode kualitatif dengan pendekatan studi kasus. Data yang digunakan dalam penelitian menggunakan data primer dan dilihat dari sumber pengumpulan data, data yang digunakan berasal dari wawancara langsung dengan pihak teller dan manager di BMT. Hasil penelitian ini menjelaskan bahwa BMT menyediakan beberapa produk simpanan dan produk pembiayaan. Untuk melakukan pengajuan pembiayaan, nasabah harus mengisi formulir terlebih dahulu kemudian melengkapi berkas-berkas yang diperlukan. Dalam penerapan pembiayaan musyarakah pada BMT Dana Barokah Muntilan sudah sesuai dengan prinsip syariah Islam dan pembagian usaha dengan profit sharing, namun bank hanya sebagai pemberi modal tidak ikut serta dalam melakukan kegiatan usaha. Bagi hasil yang ditentukan oleh BMT Dana Barokah Muntilan sebesar 2,5\%, namun masih bisa dilakukan negosiasi.
\end{abstract}

Kata Kunci: Syariah, Pembiayaan Musyarakah, Bagi Hasil. 


\section{PENDAHULUAN}

Secara umum bank merupakan suatu entitas untuk menghimpun dana dan menyalurkan kepada masyarakat dalam bentuk pembiayaan ataupun simpanan. Di Indonesia sendiri umunya terdapat dua jenis sistem perbankan, yaitu bank konvensional dan bank syariah. Seiring perkembangan perbankan yang semakin pesat, banyak bermunculan bank-bank yang berlandaskan syariah atau disebut dengan Bank Syariah. Sistem perbankan yang paling banyak digunakan di Indonesia sendiri yaitu sistem perbankan ganda atau kita biasa menyebut dengan sistem perbankan syariah. Bank syariah sendiri merupakan bank yang menjalankan kegiatan usahanya berlandaskan dengan prinsip syariah islam yang mana mengatur perjanjian hukum islam untuk menyimpan dana atau pembiayaan (Ascarya and Yumanita 2005). Sistem perbankan syariah ini telah disahkan oleh pemerintah dengan UU Nomor 21 Tahun 2008 tentang Perbankan Syariah (Presiden RI 2008).

Perbankan syariah diharapkan untuk dapat meningkatkan pelayanan jasa yang baik dan dapat mengembangkan produk yang memiliki daya saing yang tinggi sehingga nantinya akan dapat memenuhi kebutuhan masyarakat. Upaya yang bisa dilakukan dalam mengembangkan produk keuangan syariah memerlukan proses dan keahlian khusus agar dapat menciptakan produk yang bisa sesuai dengan keadaan pangsa pasar (Basyariah 2018). Setiap bank tentunya memiliki produk-produk yang ditawarkan, tanpa terkecuali bank syariah. Dalam penelitian ini, terdapat beberapa produk yang ditawarkan pada BMT Dana Barokah Muntilan. Ada dua jenis produk yang terdapat pada bank syariah ini, yaitu produk simpanan dan produk pembiayaan.

Bank syariah merupakan bank yang tidak menerapkan bunga kepada para nasabahnya. Karena bank ini menggunakan konsep hukum islam dalam menjalankan kegiatan operasionalnya yang diterapkan dalam pelayanan jasa. Salah satu pelayanan jasa yang disediakan dalam bank syariah ini adalah pembiayaan. Salah satu jenis pembiayaan yang akan penulis bahas dalam penelitian ini yaitu pembiayaan musyarakah.

Pembiayaan musyarakah merupakan akad kerjasama dari dua orang atau lebih untuk menjalankan kegiatan usahanya dimana masing-masing pihak berkontribusi dalam dana dan pembagian keuntungan ditentukan sesuai kesepakatan bersama dan untuk pembagian kerugian ditentukan sesuai proporsi modal atau sesuai dengan kesepakatan akad pertama kali (Antonio 2001). Menurut Algoud and Lewis (2007), musyarakah adalah kemitraan alam suatu usaha, dimana dua orang atau lebih menggabungkan modal atau kerja mereka untuk berbagi keuntungan, menukmati hal-hak dan tanggung jawab yang sama.

Penulis mengangkat isu tentang pembiayaan musyarakah karena dalam kaitannya dengan kegiatan usaha pihak bank, pembiayaan musyarakah banyak dipilih oleh para nasabah. Para nasabah banyak yang menggunakan pembiayaan ini untuk membantu kegiatan usaha yang akan nasabah dirikan. Biasanya nasabah yang mengajukan pembiayaan ini kekurangan modal untuk menunjang usaha. Dengan adanya pembiayaan musyarakah pihak nasabah akan terbantu dengan bantuan modal, begitu juga dengan pihak bank yang akan mendapatkan nisbah bagi hasil dari modal yang dipinjamkan. Sehingga antara kedua belah pihak samasama mendapatkan keuntungannya masing-masing. 
BMT Dana Barokah Muntilan merupakan salah satu lembaga keuangan alternatif yang menghimpun dana dari masyarakat dan menyalurkannya dalam bentuk pembiayaan. Dalam melakukan penelitian, peneliti memilih BMT Dana Barokah Muntilan karena bank ini berada pada tempat yang strategis antara pemukiman dan berdekatan dengan pasar. Dan benar saja banyak para pedagang pasar yang mempercayakan uangnya untuk disimpan di BMT, tidak sedikit pula yang meminjam uang kepada pihak BMT untuk keperluannya masing-masing. BMT Dana Barokah Muntilan memang sudah sangat terkenal diantara para para pedagang Pasar Muntilan. Selain itu mengapa peneliti memilih BMT Dana Barokah karena bank tersebut banyak melakukan transaksi pembiayaan musyarakah daripada pembiayaan yang lainnya. Dan juga peneliti telah melakukan Praktik Kerja Lapangan di BMT tersebut sehingga peneliti sudah memiliki gambaran dasar mengenai pembiayaan musyarakah, lebih mudah mendapatkan informasi, dan mengetahui masalah apa yang terjadi pada transaksi pembiayaan musyarakah. Selain itu peneliti menemukan kurang sesuainya dengan fatwa DSN-MUI perihal perhitungan bagi hasil.

Penelitian yang sudah membahas mengenai pembiayaan musyarakah dilakukan oleh (Fladira 2018) dengan hasil bahwa dalam perhitungan bagi hasil harus ditentukan nisbah terlebih dahulu, pembagian keuntungan masih belum sesuai dengan fatwa DSN-MUI, dan menggunakan prinsip profit sharing. Selain itu penelitian yang dilakukan oleh (Praseptyaningrum et al. 2019) mengemukakan bahwa terdapat ketidaksesuaian prosedur yang dilakukan pihak BMT dengan fatwa DSN-MUI, yang mana apabila terjadi kerugian pihak BMT tidak akan menanggung kerugian namun akan dilakukan reschedulling dengan memberikan keringanan jumlah angsuran dan perpanjangan dalam pengembalian modal pembiayaan. Selain itu terdapat penelitian yang mengemukan bahwa dalam perhitungan bagi hasil perbankan syariah juga tidak sesuai dengan DSN-MUI, diteliti oleh (Arfan et al. 2016). Berdasarkan penelitian tersebut maka penelitian ini bertujuan untuk mengetahui penerapan akad musyarakah berbasis bagi hasil dan produk pembiayaan serta mekanisme pembiayaan pada Baitul Maal wa Tamwil (BMT) Dana Barokah.

\section{TELAAH LITERATUR}

\section{Bank Syariah}

Bank syariah merupakan bank yang menjalankan kegiatan operasionalnya berdasarkan prinsip syariah atau prinsip hukum islam dimana pihak bank tidak memberikan bunga kepada para nasabahnya. Prinsip tersebut didasarkan pada larangan dalam islam untuk tidak membebankan bunga yang dipinjamkan kepada nasabah atau yang sering disebut dengan riba, karena dalam syariah islam kegiatan tersebut haram dilakukan dan tidak memberikan keberkahan dalam usahanya (Marimin et al. 2015). Sesuai Undang-Undang Nomor 21 Tahun 2008 tentang Perbankan Syariah, Bank Syariah adalah bank yang menjalankan kegiatan usaha berdasarkan prinsip syariah, atau prinsip hukum Islam yang diatur dalam fatwa Majelis Ulama Indonesia (MUI) seperti prinsip keadilan dan keseimbangan ('adl wa tawazun), kemaslahatan (maslahah), universalisme (alamiyah), serta tidak mengandung gharar, maysir, riba, zalim dan objek yang haram (Presiden RI 2008). Selain itu, Undang-Undang Perbankan Syariah juga mengamanahkan bank 
syariah untuk menjalankan fungsi sosial dengan menjalankan fungsi seperti lembaga baitul maal, yaitu menerima dana yang berasal dari zakat, infak, sedekah, hibah atau dana sosial lainnya dan menyalurkan kepada pengelola wakaf (nazhir) sesuai kehendak pemberi wakaf (wakif).

Bank Syariah terdiri dari Bank Umum Syariah dan Bank Pembiayaan Syariah (Pranata 2013). Kegiatan yang dilakukan oleh Bank Umum syariah yaitu yang pertama menghimpun dana dalam bentuk simpanan berupa giro, tabungan dan bentuk lainnya. Kedua, menghimpun dana dalam bentuk investasi berupa deposito, tabungan dan bentuk lainnya. Dan yang ketiga menyalurkan pembiayaan bagi hasil berdasarkan akad yang ada dalam Bank Syariah. Sedangkan kegiatan yang dilakukan Bank Pembiayaan Syariah yaitu menempatkan dana pada Bank Syariah lain dalam bentuk titipan. Kemudian, memindahkan uang, baik untuk kepentingan sendiri maupun nasabah. Dan yang terakhir menyediakan produk atau melakukan kegiatan usaha Bank Syariah lainnya sesuai dengan prinsip syariah (Pranata 2013).

\section{Baitul Maal wa Tamwil (BMT)}

Baitul Maal wa Tamwil (BMT) adalah lembaga keuangan mikro yang dalam kegiatan operasionalnya berdasarkan prinsip bagi hasil, membantu menumbuhkan UMKM dan usaha kecil masyarakat, dalam rangka untuk meningkatkan derajat dan membantu kaum yang membutuhkan (Sofhian 2017). BMT terdiri dari dua istilah, yaitu baitul maal dan baitul tamwil. Baitul maal lebih mengarah pada usaha-usaha pengumpulan dana yang non profit, seperti zakat, infaq, hibah, dan sedakah sedangkan baitul tamwil sebagai usaha untuk pengumpulan dana untuk pengembangan usaha (Sofhian 2017). Usaha-usaha tersebut menjadi bagian yang tidak terpisahkan dari BMT sebagai lembaga pendukung kegiatan ekonomi masyarakat kecil dengan berlandaskan syariah. Perbedaan BMT dengan bank konvensional yaitu terletak pada objek dana, bank konvensional bisa menarik dana dari masyarakat tanpa syarat sedangkan di BMT untuk menarik dana pada masyarakat harus menjadi anggota atau calon anggota nasabah (Ridwan 2006).

\section{Pembiayaan Musyarakah}

Pembiayaan musyarakah adalah akad kerjasama dari dua orang atau lebih untuk menggabungkan sejumlah modal yang dimiliki, dengan melakukan usaha bersama, dan pengelolaan bersama dalam menjalankan suatu kegiatan bisnis (Yusuf 2012). Pembagian hasil usaha sesuai dengan nisbah yang telah disepakati sedangkan untuk kerugiannya ditentukan sesuai dengan proporsi modal masingmasing atau sesuai akad awal. Pihak yang memberikan modal boleh ikut serta dalam menjalankan bisnisnya, tetapi hal tersebut tidak merupakan keharusan. Para pemilik modal dapat membagi pekerjaan sesuai dengan kesepakatan awal dan mereka dapat meminta gaji sesuai dengan kontribusi jasa yang mereka lakukan untuk usaha tersebut (Ascarya and Yumanita 2005).

Ada beberapa rukun musyarakah yang harus dipenuhi ketika seorang nasabah hendak mengajukan pembiayaan musyarakah. Dalam akad ini harus bisa dilaksanakan semua rukun yang ada karena apabila terdapat salah satu rukun yang tidak dilakukan, maka akad yang dilakukan rusak atau tidak sah. Berikut beberapa 
rukun yang ada yaitu ijab qabul, dua pihak yang berakad, objek akad, dan nisbah bagi hasil (Nurhayati and Wasilah 2015).

Terdapat dua jenis musyarakah, yang pertama musyarakah kepemilikan yaitu kepemilikan aset dua orang atau lebih yang diperoleh dari warisan, wasiat, atau kondisi lainnya yang mengakibatkan kepemilikan aset. Yang kedua, musyarakah akad yaitu aset yang diperoleh dari kesepakatan dua orang atau lebih untuk menggabungkan modaknya guna menjalankan usaha tertentu, semua pihak sepakat untuk berbagi keuntungan dan kerugian (Qonaatillah et al. 2019).

\section{Sistem Bagi Hasil}

Bagi hasil merupakan keuntungan yang diperoleh masing-masing mitra kerja dalam menjalankan kegiatan usahanya sesuai dengan kesepakatan bersama (Fladira 2018). Dengan adanya pembagian nisbah bagi hasil diharapkan agar tidak ada perselisihan yang terjadi yang disebabkan oleh pembagian keuntungan. Dalam melakukan pembagian nisbah usaha dilakukan pada saat awal perjanjian pembiayaan musyarakah. Dasar untuk pembagian bagi hasil harus ditentukan terlebih dahulu sesuai dengan kesepakatan. Sesuai dengan Fatwa DSN No. 15 Tahun 2000 yang menyatakan bahwa bank syariah diperbolehkan menggunakan dasar bagi hasil dengan menggunakan prinsip bagi hasil (revenue sharing) atau bisa juga dengan prinsip bagi untung (profit sharing) (MUI 2000).

\section{PSAK Nomor 106}

Pernyataan Standar Akuntansi Keuangan (PSAK) No 106 yang membahas mengenai pedoman pembiayaan musyarakah meliputi (IAI 2007): 1) Karakteristik pembiayaan Musyarakah. Karakteristik yang pertama yaitu dalam menjalankan usaha teretentu, dana atau modal yang diperoleh berasal dari para mitra masingmasing. Apabila mitra meminjam dana dari entitas lain, mitra dapat mengembalikan dana dan bagi hasil sesuai dengan nisbah yang telah disepakati baik pengembalian secara bertahap ataupun sekaligus. Kedua, investasi musyarakah yang diberikan oleh pihak bank dapat berupa kas atau non kas, bisa juga aset tidak berwujud. Ketiga, menyediakan jaminan atas kesalahan atau kelalaian yang disengaja, karena setiap mitra tidak dapat menjamin dana dari setiap mitra maka setiap mitra dapat meminta jaminan tersebut kepada mitra lain. Keempat, Apabila terdapat kesalahan yang terjadi dan belum ada kesepakatan awal. Maka harus dibuktikan oleh pihak yang berwenang. Kelima, pendapatan dan kerugian diperoleh para mitra berdasarkan proporsi dana yang disetorkan dalam usahanya baik dalam bentuk kas atau non kas. Keenam, apabila salah satu mitra memberikan dana usahanya lebih besar dari pada lainnya, maka keuntungan yang diperoleh lebih besar dibandingkan dengan mitra lainnya. Ketujuh, Jumlah bagi hasil yang diperoleh para mitra berdasarkan dari nisbah yang telah disepakati pada saat periode akad bukan berdasarkan jumlah investasi yang telah diberikan (Linaria and Chintya 2017). Yang terakhir, pengelolaan transaksi usaha yang berkaitan dalam investasi musyarakah telah dibukukan secara tersendiri. Artinya dalam pembiayaan musyarakah, para mitra telah sepakat untuk mengumpulkan dananya masing-masing yang akan digunakan untuk menjalankan usahanya, dalam investasi musyarakah, dapat berupa kas, non kas atau aset tidak berwujud. Kerugian yang diperoleh akan ditanggung bersama-sama dan untuk 
mengantisipasi adanya kesalahan dalam usahanya, setiap mitra diwajibkan memberikan jaminan sebagai alat pengaman dalam akad.

2) Pengakuan dan pengukuran pembiayaan musyarakah, dalam PSAK Nomor 106 paragraf 27, pengakuan investasi musyarakah dapat diakui apabila adanya penandatanganan perjanjian akad dan melakukan penyerahan aset kas ataupun non kas kepada mitra aktif (Hanjani et al. 2019). Pengukuran aset kas dalam investasi musyarakah dinilai berdasarkan dengan jumlah aset yang diserahkan. Sedangkan aset non kas dinilai sebesar nilai wajar dan apabila terdapat selisih antara nilai buku dan nilai aset non kas, maka akan dinilai sebagai selisih penilaian aset musyarakah (Sari 2014). 3) Penyajian dan pengungkapan, penyajian pembiayaan musyarakah dilakukan dengan mencatat semua kegiatan usahanya dalam laporan keuangan secara terperinci (Linaria and Chintya 2017). Pengungkapan pembiayaan musyarakah yaitu mitra usaha mengungkapkan halhal yang terkait dengan pembiayaan musyarakah tetapi tidak terbatas pada isi perjanjian dalam akad dan juga mitra aktif (Linaria and Chintya 2017).

Penelitian Fladira (2018) memberikan hasil bahwa ada prosedur-prosedur yang harus dipenuhi apabila nasabah akan mengajukan permohoman pembiayaan yaitu dengan mengisi formulir terlebih dahulu dan harus melengkapi syarat-syarat yang diperlukan dalam pengajuan pembiayaan. Dalam menentukan bagi hasil antara pihak bank dan nasabah, pertama-tama harus dilakukan perhitungan nisbah terlebih dahulu. Pembagian keuntungan yang dilakukan oleh pihak bank masih belum sesuai dengan apa yang sudah dijelaskan dalam fatwa DSN-MUI. Hal yang membedakan penelitian (Fladira 2018) dengan penelitian ini yaitu penelitian fokus pada implikasi pembiayaan musyarakah pada BMT sedangkan penelitian (Fladira 2018) fokus pada prinsip bagi hasil yang disesuaikan dengan fatwa DSNMUI.

Penelitian Praseptyaningrum et al. (2019) menunjukkan bahwa terdapat ketidaksesuaian dalam prosedur yang dilakukan pihak bank perihal terjadi kerugian. Di dalam fatwa DSN-MUI apabila terjadi kerugian harus ditanggung oleh kedua mitra kerja, sedangkan dalam pelaksanaannya di BMT Batik Mataram harus dilakukan reschedulling yang mana pihak bank hanya akan memberikan keringan jumlah angsuran dan perpanjangan waktu jatuh tempo pengembalian modal yang dipinjam. Dan pada perhitungan bagi hasil juga tidak sesuai dengan fatwa DSN-MUI, menurut DSN-MUI perhitungan bagi hasil harus didasarkan pada keuntungan setiap periode usaha namun pada kenyataannya pada BMT Batik Mataram perhitungannya didasarkan pada besaran pokok pinjaman. Hal yang membedakan penelitian (Praseptyaningrum et al. 2019) dengan penelitian ini adalah penelitian ini fokus pada mekanisme pembiayaan pada BMT Dana Barokah Muntilan dan juga memberikan gambaran perhitungan secara umumnya. Sedangkan pada penelitian (Praseptyaningrum et al. 2019) fokus pada kesesuaian pelaksanaan pembiayaan dengan DSN-MUI dan juga cara pencatatan jurnalnya pada buku besar akuntansi.

\section{METODE PENELITIAN}

Jenis penelitian yang dilakukan peneliti adalah dengan menggunakan metode kualitatif. Menurut Saryono (2010), metode kualitatif merupakan penelitian yang digunakan untuk menyelidiki, menemukan, menggambarkan, dan 
menjelaskan kualitas atau keistimewaan dari pengaruh sosial yang tidak dapat dijelaskan, diukur atau digambarkan melalui pendekatan kuantitatif. Tujuan dari penelitian kualitatif adalah agar peneliti menemukan jawaban dari suatu fenomena atau pertanyaan secara sistematis.

Pendekatan yang digunakan dalam penelitian ini yaitu dengan pendekatan studi kasus. Pendekatan ini biasanya digunakan untuk meneliti suatu kasus atau fenomena secara mendalam untuk mempelajari latarbelakang, keadaan, dan interaksi yang terjadi. Fenomena yang ditemukan harus disajikan secara apa adanya dan tanpa manipulasi.

Data yang digunakan dalam penelitian ini yaitu data primer. Data ini diperoleh langsung dari subjek penelitian yaitu BMT Dana Barokah Munutilan dengan melakukan wawancara langsung dengan teller dan manager bank yang berhubungan dengan objek yang diteliti. Alasan dipilihnya subjek penelitian tersebut karena pihak teller lebih mengetahui lebih dalam mengenai transaksi dan kendala yang ada pada BMT. Sementara itu manager lebih mengetahui informasi yang lebih luas lagi perihal objek penelitian.

Metode pengumpulan data yang digunakan peneliti dalam penelitian ini yaitu dengan teknik wawancara. Wawancara yang dilakukan peneliti dengan tatap muka dan melalui media alat komunikasi secara terstuktur dengan pihak bank. Secara singkat informasi yang diperoleh dalam wawancara yaitu, pihak BMT memiliki beberapa jenis pembiayaan yang ditawarkan namun pembiayaan musyarakah yang paling dominan. Untuk melakukan pengajuan pembiayaan harus mengisi formulir terlebih dahulu, kemudian melengkapi berkas-berkas yang dibutuhkan, dan juga untuk melakukan pengajuan pembiayaan harus memiliki jaminan.

Dalam analisis data, langkah-langkah yang dilakukan dalam penelitian ini yaitu mengumpulkan semua data yang diperoleh untuk dianalisis. Kemudian membaca keseluruhan data yang diperoleh dan memilih mana yang akan digunakan dalam penelitian. Setelah itu dianalisis lebih detail lagi agar lebih mudah lagi dalam mengkategorikan data yang akan digunakan. Langkah yang terakhir yaitu dengan mengambil kesimpulan mengenai pengolahan data. Dalam penelitian ini pendekatan yang digunakan dalam penyampaian hasil analisis yaitu dengan pendekatan naratif yang meliputi tentang pembahasan kronologi peristiwa dan juga terdapat gambar yang memudahkan dalam menyajikan pembahasan.

Untuk menjamin keabsahan data dan terjamin keakuratan data yang digunakan dalam penelitian ini, peneliti melakukan "Cross Check" dengan melihat kesesuaian antara data yang diperoleh dari wawancara, data yang diperoleh melalui media internet, dan observasi mengenai penerapan atau pelaksanaan pembiayaan musyarakah dan perhitungan bagi hasil dari pembiayaan musyarakah di BMT Dana Barokah Muntilan.

\section{HASIL DAN PEMBAHASAN PENELITIAN}

\section{Produk-Produk Yang Ada Pada BMT Dana Barokah Muntilan}

BMT Dana Barokah memiliki beberapa produk simpanan, yaitu yang pertama simpanan wadi'ah adalah tabungan yang dapat dilakukan hampir setiap hari sesuai dengan keinginan nasabah, transaksi ini dapat berupa setoran ataupun pengambilan. Dalam melakukan simpanan wadi'ah tidak ditentukan berapa 
nominal yang harus disetorkan dan bisa kapan saja menabungnya. Tabungan ini yang paling banyak digunakan dalam kesehariannya. Simpanan ini menjadi yang paling banyak digunkana dan diminati oleh para nasabah, karena simpanan ini tidak memiliki jumlah minimal dalam menabung. Kedua, simpanan pendidikan adalah tabungan yang digunakan untuk mempersiapkan biaya pendidikan bagi nasabah kedepannya. Para nasabah bisa menyimpan uangnya kepada pihak bank yang nantinya akan diberikan buku tabungan yang khusus untuk dapat menyetorkan uagnya untuk keperluan pendidikan. Namun selama penelitian, belum pernah melayani nasabah yang melakukan simpanan pendidikan ini. Ketiga, simpanan idul fitri adalah tabungan nasabah yang dipersiapkan untuk hari raya, agar nantinya sebelum hari raya nasabah bisa memperoleh uang yang bisa digunakan untuk kegiatan hari raya. Biasanya dalam menggunakan simpanan ini, para nasabah ditentukan minimal penyetoran yaitu sebesar Rp 50.000/bulan. Dan secara periodik diadakan undian atau bonus bagi para nasabah yang menggunakan simpanan ini. Bagi hasil simpanan ini dengan porsi 30:70. Simpanan ini jarang diminati oleh para nasabah, selama penelitian belum pernah melayani simpanan ini. Keempat, simpanan qurban adalah tabungan yang dipersiapkan untuk hari raya qurban. Dalam simpanan ini ditentukan minimal tabungan yang disetorkan yaitu sebesar Rp 75.000/bulan. Bagi hasil dalam simpanan ini juga sama dengan simpanan sebelumnya yaitu 30:70. Di BMT sendiri hanya sedikit nasabah yang melakukan simpanan qurban. Kelima, simpanan lembaga adalah tabungan yang dikhususkan hanya untuk lembaga, organisasi, dan instansi. Simpanan ini diperuntukkan sebagai bentuk kerja sama yang saling menguntungkan antara kedua belah pihak. Keenam, simpanan berjangka adalah tabungan yang memiliki jangka waktu antara lain 3 bulan, 6 bulan, dan 12 bulan. Biasanya jumlah setoran minimal Rp 1.000.000 dengan bagi hasil 50:50. Ada beberapa jenis tabungan berjangka yang ada yaitu premium dengan simpanan berjangka 12 bulan dengan dana pengendapan minimal 50 juta, platinum dengan simpanan berjangka 24 bulan dengan dana pengendapan minimal 75 juta, dan gold selama 24 bulan dengan dana pengendapan minimal 100 juta. Dan terakhir, simpanan arshika adalah tabungan yang hanya ditetapkan selama 3 tahun atau 36 bulan saja. Simpanan ini memiliki minimal setoran sebesar Rp 100.000/bulan. Simpanan arshika terdapat hadiah yang diundi setiap periode sebanyak 3 kali dan juga terdapat bonus tambahan sebesar Rp 250.000 di akhir periode. Simpanan ini juga banyak diminati oleh para nasabah setelah simpanan wadi'ah, karena simpanan ini sudah jelas berapa jumlah yang nantinya akan diterima oleh nasabah. Simpanan ini cocok untuk para nasabah yang ingin memiliki uang untuk jangka panjang, karena simpanan arshika akan diperoleh setelah 3 tahun menabung.

Dari beberapa produk simpanan yang ada pada BMT Dana Barokah, hanya ada beberapa produk simpanan yang digunakan oleh para nasabah yaitu simpanan wadi'ah, simpanan berjangka, dan simpanan arshika. Alasan kenapa simpanan wadi'ah yang paling banyak digunakan karena pada simpanan tersebut tidak banyak syarat yang harus dilakukan oleh para nasabah. Jumlah yang ditabung pun tidak memiliki jumlah minimal ataupun maksimal yang harus disetorkan. Begitu pula dengan penarikannya, tidak ada jumlah maksimal dan minimalnya. Oleh sebab itu banyak para nasabah yang menggunakan simpanan wadi'ah. 
BMT Dana Barokah Muntilan terdapat beberapa produk pembiayaan yang ditawarkan yaitu Pembiayaan BBA (Bai'u Bitsanab Ajil) adalah pembelian barang secara kredit dengan cara pihak BMT memberikan pinjaman dana kepada nasabah yang nantinya digunakan untuk membeli barang dengan akad pinjaman. Akad tersebut berisi bahwa nasabah akan membayar barang tersebut dengan cara mengangsur dan dengan harga yang telah disepakati bersama. Pembiayaan ini jarang dilakukan, namun pihak BMT tetap menawarkan produk pembiayaan ini kepada nasabah. Kedua, Pembiayaan Mudharabah yaitu kerjasama usaha antara dua pihak, dimana pihak pertama yaitu bank sebagai pemilik dana (shohibul maal) dan nasabah sebagai pengelola dana (mudharib) dengan nisbah (Ilyas, 2015). Dalam pembiayaan ini keuntungan dibagi sesuai dengan kesepakatan, sedangkan kerugian ditanggung oleh pemilik modal. Pembiayaan ini juga banyak dipilih oleh para nasabah yang ingin memgembangkan usahanya atau yang akan membuka UMKM baru. Ketiga, Pembiayaan Musyarakah yaitu kerjasama usaha dengan menggabungkan modal dari dua orang atau lebih dan melakukan bersama kegiatan usahanya. Dalam pembagian keuntungan sesuai dengan kesepakatan sedangkan kerugian di tanggung secara bersama sesuai kontribusi modal atau sesuai kesepakatan awal. Produk pembiayaan keempat yaitu Qurdhul Hasan adalah pinjaman yang dilakukan tanpa memberikan imbalan sosial dan hanya mengembalikan peminjaman pokoknya saja. Pembiayaan ini hanya dikhususkan bagi nasabah yang memenuhi syarat dengan pengembalian tanpa bagi hasil. Ada beberapa nasabah yang menggunakan pembiayaan ini, karena memang sudah disurvei dan memenuhi syarat yang ditentukan oleh pihak BMT. Kelima, Piutang Murabahah yaitu kegiatan menjual barang dengan melakukan kesepakatan harga dan keuntungan sesuai kesepakatan bersama dengan pengambilan pinjaman pokok di akhir bulan. Contoh: Ibu Amelia meminjam uang sebesar Rp 3.000.000 di BMT Dana Barokah Muntilan pada tanggal 18 November 2011 dengan menggunakan pembiayaan murabahah dengan jangka waktu selama 6 bulan.

$$
\begin{aligned}
\text { Uang yang diterima } & =\operatorname{Rp} 3.000 .000-(\operatorname{Rp} 3.000 .000 \times 2 \%) \\
& =\operatorname{Rp} 2.940 .000 \\
\text { Besar angsuran ke-6 } & =\text { Pokok + Bagi Hasil } \\
& =\operatorname{Rp} 3.000 .000 \times 3 \% \\
& =\operatorname{Rp} 90.000
\end{aligned}
$$

Jadi, Ibu Amelia harus mengangsur kepada pihak bank setiap bulannya Rp 90.000, bulan terakhir Rp 3.090.000 yang terhitung mulai tanggal 18 November 2011 sampai 18 Mei 2012.

Produk pembiayaan yang disediakan BMT Dana Barokah Muntilan dapat dibilang cukup banyak, namun pembiayaan yang sering digunakan atau yang paling disukai oleh para nasabah adalah pembiayaan musyarakah. Karena dengan menggunakan produk tersebut, nasabah merasa terbantu dengan modal yang diberikan oleh pihak bank. Yang menyebabkan produk pembiayaan musyarakah banyak dicari karena posisi BMT berada di dekat pasar sehingga mendorong para pedagang ataupun masyarakat lain untuk meminjam dananya agar bisa mengembangkan dagangannya ataupun yang akan mendirikan usaha baru.

\section{Mekanisme Pembiayaan Pada BMT Dana Barokah Muntilan}

Syarat-syarat yang harus dipenuhi oleh para nasabah yang mengajukan pembiayaan yaitu terdapat usaha yang layak dibiayai, ada uang minimal 10\% dari 
jumlah pembayaran atau pinjaman, menyertakan fotocopy KTP/KK yang bersangkutan suami istri atau saudara. Memperoleh persetujuan keluarga, suami istri, orang tua atau saudara. Meminta rekomendasi atau surat keterangan takmis setempat. Dan syarat terakhir, pencarian pembiayaan dilakukan setelah syaratsyarat sudah komplit dan terdapat ketentuan lain-lain seperti: Jaminan, seperti sertifikat rumah atau tanah, surat kendaraan. Biaya administrasi $2 \%$ dari pembiayaan serta materai 3.000 atau 6.000 .

Bagi nasabah yang ingin mengajukan permohonana pembiayaan, terdapat langkah-langkah yang harus dilakukan: Pertama nasabah mengajukan permohonan pembiayaan musyarakah. Dalam hal ini nasabah harus datang ke BMT Dana Barokah Muntilan untuk mengisi formulir yang telah diberikan oleh pihak teller. Nasabah juga harus membawa dokumen-dokumen yang dibutuhkan yang telah menjadi persyaratan pihak BMT. Kedua survei, setelah pihak bank melakukan peninjauan terhadap berkas nasabah dan sudah terbukti akan kebenaran datanya. Selanjutnya pihak bank akan datang untuk meninjau lokasi yang akan menjadi objek pembiayaan. Dan memastikan apakah lokasi yang diberikan memang benar adanya. Ketiga wawancara, wawancara dilakukan oleh calon nasabah pembiayaan dengan pihak BMT yang bertujuan untuk mengetahui usaha apa yang akan dijalankan oleh nasabahnya dan juga untuk mengetahui apakah nasabah tersebut bisa melaksanakan kewajibannya dengan baik. Keempat peninjauan berkas nasabah. Tujuan peninjauan berkas yaitu agar mengetahui apakah nasabah sudah melengkapi persyaratan yang diberikan oleh pihak BMT. Dan juga untuk memastikan keaslian data yang diberikan. Kelima keputusan pembiayaan, dalam hal ini pihak bank akan memutuskan apakah akan diterima atau ditolak. Apabila pembiayaan yang diajukan diterima nantinya pihak bank akan menghubungi dan melakukan akad pembiayaan. Keenam pembacaan akad, setelah pihak bank dan nasabah membicarakan mengenai akad pembiayaan, pihak bank akan membacakan ulang apa saja perjanjian yang telah disepakati bersama. Untuk memastikan dalam akad tersebut tidak terjadi kesalahpahaman dan sesuai dengan kesepakatan kedua belah pihak. Ketujuh pembayaran angsuran, pembayaran angsuran oleh nasabah dilakukan dengan cara pengembalian modal yang telah dipinjam dan bagi hasil yang diterima pihak bank dengan cara mengangsur setiap bulan sampai batas waktu yang telah disepakati bersama.

\section{Skema Pembiayaan Musyarakah Pada BMT Dana Barokah Muntilan}

BMT Dana Barokah Muntilan merupakan salah satu lembaga keuangan untuk menghimpun dan menyalurkan dananya. BMT ini telah menyediakan produk yang ditawarkan kepada nasabah berupa simpanan dan pembiayaan. Apabila nasabah yang ingin mengajukan pembiayaan musyarakah terdapat langkah-langkah yang harus dilakukan seperti Gambar 1. Pertama, nasabah harus melakukan permohonan kepada pihak bank dengan mengisi formulir. Kedua, pihak bank akan melakukan survei ke tempat usaha atau menelusuri barang yang menjadi jaminan. Ketiga, akan dilakukan wawancara oleh pihak bank. Keempat, akan dilakukan peninjauan ulang berkas yang telah diberikan. Kelima, pihak manager akan memberikan keputusan apakah diterima atau ditolak. Keenam, apabila diterima akan di proses pembuatan akad atau perjanjian. Ketujuh pihak teller akan memberikan uangnya dan juga kartu angsuran pembiayaan. 


\section{Gambar 1 Mekanisme Pengajuan Pembiayaan Musyarakah}

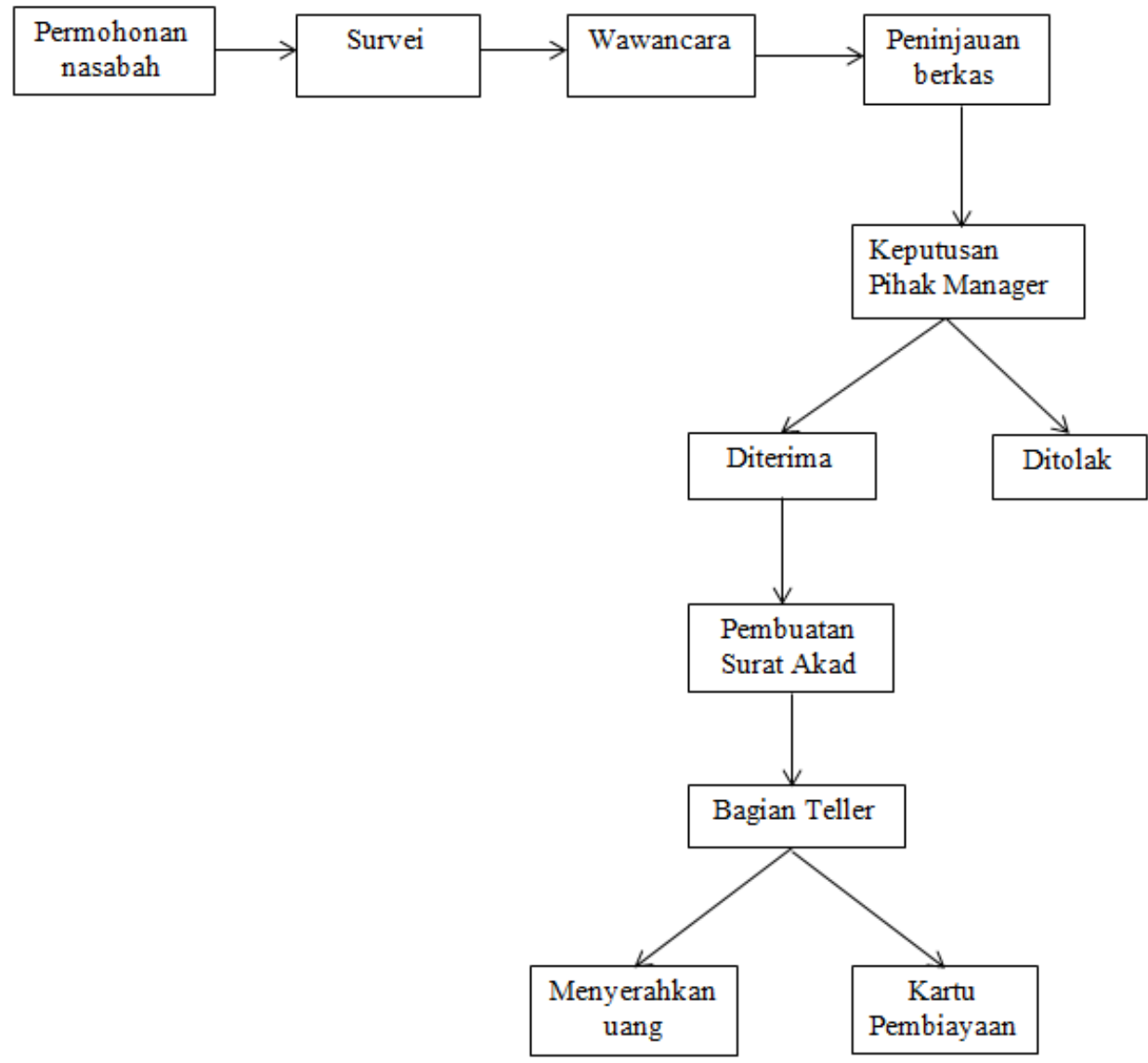

\section{Penerapan Pembiayaan Musyarakah Pada BMT Dana Barokah Muntilan}

Pembiayaan musyarakah yaitu kerjasama yang terjadi diantara pemilik modal yang menggabungkan modal dan melakukan usaha secara bersama dengan pembagian keuntungan sesuai dengan kesepakatan sedangkan kerugian di tanggung secara bersama sesuai kontribusi modal atau sesuai kesepakatan. Dasar hukum dari pembiayaan ini salah satunya yaitu al hadits dari Abu Hurairah Rasulullah SAW. bersabda, sesungguhnya Allah azza wa jallah berfirman "aku adalah pihak ketiga dari dua orang yang berserikat selama salah satu tidak ada yang mengkhianati pihak yang lain. Jika salah satu pihak telah berkhianat, aku keluar dari mereka" (HR. Abu Daud). Hadis tersebut menjelaskan bahwa Allah memberikan pernyataan bahwa mereka yang bersekutu dalam sebuah usaha akan mendapat perniagaan dalam arti Allah akan menjaganya selain itu Allah akan memberikan pertolongan namun Allah juga akan melaknat usaha mereka yang mengkhianati perjanjian.

Dalam penerapan pembiayaan musyarakah di BMT Dana Barokah Muntilan, pihak BMT mengaplikasikan pembiayaan dengan memberikan porsi dalam bentuk pemberian modal kerja. Pihak BMT hanya akan membantu nasabah yang telah mengajukan pembiayaan ini dengan memberikan dana yang dibutuhkan oleh nasabahnya. Dalam pembiayaan ini antara kedua belah pihak akan membicarakan perjanjian apa saja yang akan disepakati. Awal mulanya pihak nasabah yang akan mengajukan pembiayaan ini mengisi formulir sesuai 
dengan kehendak yang akan diajukan kepada pihak bank kemudian nantinya pihak bank akan membicarakan dengan nasabah, apa saja kesepakatan yang akan dibuat.

Dengan adanya pembiayaan musyarakah, kebutuhan nasabah untuk mendapatkan tambahan modal kerja akan terpenuhi dan akan memperlancar kegiatan usahanya. Disamping itu pihak bank juga akan diuntungkan dengan adanya pembiayaan ini. Karena dengan adanya pembiayaan musyarakah, pihak bank akan mendapatkan bagi hasil dari kegiatan usaha yang dilakukan nasabah tersebut. Dalam pembiayaan musyarakah, bank hanya akan memberikan sebagian dari total keseluruhan modal yang dibutuhkan. Misalnya saja pihak bank memberikan $70 \%$ dari total keseluruhan dan sisanya 30\% menggunakan modal dari nasabah sendiri. Porsi keuntungan yang didapatkan nasabah sesuai dengan kesepakatan awal yang sudah disepakati bersama, begitu juga dengan kerugian sesuai dengan akadnya.

Ada beberapa perbedaan pembiayaan musyarakah pada bank syariah dengan Baitul Maal Wat Tamwil (BMT). Salah satunya dalam pembagian nisbah bagi hasil produk tabungan, dimana pihak BMT menentukan bagi hasil yang lebih kecil dibandingkan dengan bank syariah. Karena memang dari segi modal sendiri, pihak BMT memiliki modal yang relatif kecil dari pada bank syariah, sistem profit and loss sharing yang berbeda, serta tidak adanya pembebanan biaya administrasi.

\section{Perhitungan Bagi Hasil Pembiayaan Musyarakah Pada BMT Dana Barokah Muntilan}

Bagi hasil merupakan keuntungan yang diperoleh masing-masing mintra kerja dalam menjalankan kegiatan usahanya sesuai dengan kesepakatan bersama (Flarida 2018). Di BMT Dana Barokah sendiri penentuan bagi hasil disesuaikan sebesar 2,5\% namun ada juga nasabah yang tidak diberatkan untuk memberikan bagi hasilnya. Hal tersebut bisa terjadi apabila nasabah memang tidak mampu untuk memberikannnya dan juga oleh pihak BMT sudah dilakukan survei secara mendalam sehingga keputusan tersebut diambil. Sesuai dengan hasil wawancara yang dilakukan dengan pihak teller bernama Ade Noermawati A.Md "Besarnya bagi hasil yang diberikan kepada nasabah yaitu 2,5\%, namun juga ada nasabah yang tidak diberatkan untuk memberikan nisbahnya. Karena dilihat dari faktor ekonomi memang tidak bercukupan sehingga pihak BMT memutuskan untuk tidak memberikan sistem bagi hasil. Namun tentunya telah dilakukan survei yang mendalam sehingga keputusan tersebut diambil". Pihak BMT akan memberitahu kepada nasabah besaran nisbah bagi hasil yang akan diberikan. Setelah kedua belah pihak menyetujuinya, pihak teller akan membuatkan surat pertnyataan akadnya.

Perhitungan bagi hasil di BMT sendiri masih dilakukan secara manual. Ketika pihak nasabah datang ke BMT untuk melakukan proses akadnya, pihak bank akan melakukan perhitungan bagi hasil sesuai dengan hasil wawancara dan survey yang dilakukan. Karena proses perhitungan bagi hasil dilakukan secara manual maka pihak teller akan langsung menghitung pada slip pembiayaan musyarakah dan kartu pembiayaan, tentunya dibantu dengan alat hitung kalkulator agar tidak salah. Di dalam slip atau kartu pembiayaan akan tertera berapa modal yang dipinjam, nisbah bagi hasilnya, tanggal jatuh tempo, dan berapa lama 
angsuran akan dilakukan. Contoh: Sarah meminjam uang di BMT Dana Barokah Muntilan pada tanggal 12 Januari 2011 sebesar Rp 1.000.000 yang digunakan untuk keperluan modal usahanya dengan menggunakan pembiayaan musyarakah dengan jangka waktu 1 tahun (12 bulan).

$$
\begin{aligned}
\text { Uang yang diterima } & =\operatorname{Rp} 1.000 .000-(\operatorname{Rp} 1.000 .000 \times 2,5 \%) \\
& =\operatorname{Rp} 980.000 \\
& =\text { Pokok }+ \text { Bagi Hasil } \\
& =(\operatorname{Rp} 1.000 .000: 12)+(\operatorname{Rp} 1.000 .000 \times 2,5 \%) \\
& =\operatorname{Rp} 84.000+\operatorname{Rp} 25.000 \\
& =\operatorname{Rp} 109.000
\end{aligned}
$$

Jadi, Sarah harus mengangsur pembiayaan ke BMT setiap bulannya sebesar Rp 109.000 yang terhitung sejak tanggal 12 Januari 2011 sampai 12 Februari 2012.

\section{KESIMPULAN}

BMT Dana Barokah Muntilan merupakan salah satu lembaga keuangan untuk menghimpun dana dan menyalurkan dananya kepada masyarakat. Pihak BMT menawarkan beberapa produk simpanan dan pembiayaan. Pembiayaan yang paling banyak digunakan dan diminati oleh nasabah yaitu pembiayaan musyarakah, khususnya oleh nasabah yang memang benar-benar secara ekonomi tidak mampu namun ingin membuka usaha. Pihak BMT tidak akan memberatkan sistem bagi hasil. Apabila nasabah ingin mengajukan pembiayaan harus mengisi formulir permohonan pembiayaan dan melengkapi berkas-berkas yang dibutuhkan. Penerapan pembiayaan musyarakah di BMT Dana Barokah Muntilan memang secara garis besar sesuai dengan teori yang ada atau prinsip syariah. Hanya saja dalam penerapannya tidak sepenuhnya memenuhi standar yang ada. Untuk pembagian bagi hasil dalam pembiayaan musyarakah pihak BMT memberikan sebesar 2,5\%, namun apabila setelah dilakukan survei pihak nasabah secara ekonomi tidak mampu. Pihak BMT tidak akan membebankan bagi hasilnya. Setelah dilakukan negosiasi mengenai perhitungan bagi hasil, pihak BMT atau teller akan membuat akad perjanjiannya, menghitung secara manual bagi hasilnya dalam slip pembiayaan dan juga kartu pembiayaan.

Bagi peneliti selanjutnya, sebaiknya menjelaskan lebih rinci lagi mengenai pembiayaan musyarakah beserta dengan contoh transaksinya pada pihak bank. Karena dalam penelitian ini, peneliti tidak mendapatkan data mengenai berapa banyak nasabah yang mengajukan pembiayaan dan juga transaksi pembiayaan yang ada. Bagi pihak BMT, lebih konsisten lagi dalam menerapkan perlakuan pembiayaan musyarakah yang sesuai dengan Fatwa DSN-MUI agar dalam penerapannya memiliki landasan yang kuat. Dan juga lebih dipermudah lagi untuk nasabah yang akan memulai usahanya atau pembiayaan ini di khususkan untuk sektor UMKM agar nantinya dapat membuka lowongan pekerjaan untuk masyarakat yang membutuhkan dan juga dalam rangka untuk meningkatkan kesejahteraan rakyat kecil.

\section{DAFTAR PUSTAKA}

Algoud, Latifa M. dan Mervyn K Lewis. 2007. Islamic Banking. Jakarta: Serambi Ilmu Semesta. 
Antonio, Muhammad Syafei. 2001. Bank Syariah: dari Teori ke Praktik. Jakarta: Gema Insani Press.

Arfan, Abbas, Saifullah, dan Fakhruddin. 2016. "Implementasi Prinsip Bagi Hasil dan Manajemen Risiko dalam Produk-Produk Pembiayaan Perbankan Syariah di Kota Malang”. INFERRENSI, Jurnal Penelitian Sosial Keagamaan 10 (1): 213-238. https://doi.org/10.18326/infsl3.v10i1.213238.

Ascarya, dan Diana Yumanita. 2005. Bank Syariah: Gambaran Umum. Jakarta: Pusat Pendidikan dan Studi Kebanksentralan (PPSK) Bank Indonesia.

Basyariah, Nuhbatul. 2018. "Analisis Implementasi Pembiayaan Musyarakah Muntanaqishah pada Perbankan Syariah di Indonesia". MUQTASID: Jurnal Ekonomi dan Perbankan Syariah 9 (2): 120-133. https://doi.org/10.18326/muqtasid.v9i2.120-133.

Fladira, Ratna. 2018. "Analisis Pelaksanaan dan Perhitungan Bagi Hasil Pembiayaan Musyarakah di BMT Binamas Purworejo”. Jurnal Pendidikan Ekonomi 7 (4): 375-388.

Hanjani, Andreani, Andika Ranto Pratama, dan Parwoto. 2019. "Penerapan PSAK 106 pada Pembiayaan Musyarakah di BMT Batik Mataram". Jati: Jurnal Terapan Akuntansi Indonesia 2 (2): 48-51. https://doi.org/10.18196/jati.020217.

Ikatan Akuntan Indonesia. 2007. Pernyataan Standar Akuntansi Keuangan (PSAK) 106 Tentang Pembiayaan Musyarakah.

Ilyas, Rahmat. 2015. "Konsep Pembiayaan Dalam Perbankan Syari'ah". Jurnal Penelitian 9 (1): 183-204. http://dx.doi.org/10.21043/jupe.v9i1.859.

Linaria, dan Aprina Chintya. 2017. "Penerapan PSAK No. 106 Pada Perlakuan Akuntansi Musyarakah di BMT Al-Ihsan Metro Lampung”. Equilibrium: Jurnal Ekonomi Syariah $5 \quad$ (1): 32-46. https://journal.iainkudus.ac.id/index.php/equilibrium/article/view/2466.

Majelis Ulama Indonesia. 2000. Prinsip Distribusi Hasil Usaha dalam Lembaga Keuangan Syariah. Jakarta: DSN-MUI.

Marimin, Agus, Abdul Haris Romdhoni, dan Tira Nur Fitria. 2015. "Perkembangan Bank Syariah di Indonesia" Jurnal Ilmiah Ekonomi Islam 1 (2): 75-87.

Nurhayati, Sri, dan Wasilah. 2015. Akuntansi Syariah Di Indonesia. Jakarta: Salemba Empat.

Pertiwi, Petty Amalia. 2017. "Penerapan Sistem Bagi Hasil dan Perlakuan Akuntansi Pembiayaan Mudharabah". Jurnal Ilmu dan Riset Akuntansi (JIRA) 6 (7): 1-16.

Pranata, Danu. 2013. Manajemen Perbankan Syariah. Jakarta: Salemba Empat.

Praseptyaningrum, Farida, Desi Susilawati, dan Linda Kusumawati Wardana. 2019. "Analisis Prosedur dan Perhitungan Bagi Hasil Pembiayaan Musyarakah di BMT Batik Mataram Wirobrajan Yogyakarta". Jati: Jurnal Akuntansi Terapan Indoensia 2 (1): 1-7.

Presiden Republik Indonesia. 2008. Peraturan Pemerintah Nomor 21 Tahun 2008 Tentang Bank Syariah.

Qonaatillah, Iffah, Jeni Susyanti, dan M. Khoirul ABS. 2019. "Analisis Kendala Penerapan Pembiayaan Akad Mudharabah, Murabahah, dan Musyarakah 
pada BMT UGT Sidogiri Cabang Malang Kota”. Jurnal Ilmiah Riset Manajemen 8 (2): 28-46.

Ridwan, Muhammad. 2006. Sistem dan Prosedur Pendirian Baitul Maal Wattamwil (BMT). Yogyakarta: Citra Media.

Sari, Interestha Profita. 2014. Penerapan PSAK 106 untuk Akuntansi Investasi Musyarakah pada PT Bank Syariah Mandiri Tbk Cabang Jember. Skripsi Universitas Jember.

Saryono. 2010. Metode Penelitian Kualitatif. Bandung: PT. Alfabeta.

Sofhian. 2017. "Baitul Maal wat Tamwi (BMT) Berbasis Kearifan Lokal Gorontalo." Al-Ulum 17

(1): 166-182. https://doi.org/10.30603/au.v17i1.112.

Yusuf, Muhammad. 2012. "Analisis Penerapan Akuntansi Musyarakah terhadap PSAK 106 pada Bank Syariah X”. Binus Business Review 3(1), 273-285. 